\title{
TEST AND DESIGN OF STAINLESS STEEL WELDED I-COLUMNS
}

\author{
Baofeng Zheng ${ }^{1}$, Ganping Shu ${ }^{1}$ and Xiaoming Shen ${ }^{2}$ \\ ${ }^{1}$ School of Civil Engineering, Southeast University, No. 2 Sipailou, Nanjing, China, 210096 \\ ${ }^{2}$ ARTS Group Co., Ltd, Suzhou, China, 215020
}

\begin{abstract}
This paper describes a series of tests on austenitic stainless steel welded I-columns. Two stub column tests and seven long column tests were carried out. Geometric dimensions, local and overall imperfections of the columns were measured. Material properties of the columns were obtained from tensile coupon and stub column tests. The material enhancement due to the shear cutting in the fabrication of the columns was also measured. The effects of this material enhancement and the residual stresses caused in welding, on the flexural buckling strengths of columns were evaluated using finite element method. The strengths obtained from long column tests were compared with the strengths predicted by European design code (Eurocode3: Part 1.4) and American design code (SEI/ASCE-8-02). It is concluded that the column curve for welded I-column buckled in minor axis of European design code is more reliable in the strength predictions for welded I-columns buckled in major axis and columns buckled in minor axis.
\end{abstract}

Keywords: Stainless steel, Welded I-column, Test, Design, Column curve

\section{INTRODUCTION}

Stainless steel sections are increasingly used in architectural and structural applications because of their superior corrosion resistance, ease of maintenance and pleasing appearance in recent years.

Stainless steel column behaviors have been investigated both experimentally and theoretically. Most of the previous researches focus on the behavior of the cold formed stainless steel columns. Few researches have been reported on the welded I-columns. Kuwamura[1], Saliba and Gardner[2], and Yuan et al. [3] reported tests on stainless steel stub column tests of welded I-sections. Bredenkamp and Van den Berg [4] carried out two stub column tests and thirteen long column tests on welded I-columns of Grade 3CR12. Burgan et al. [5] reported fifteen long column tests on welded I-columns of Grade S304 and S31803. Up to date, a total of twenty eight long column tests are available on the welded I-sections.

On the design code side, American design code (SEI/ASCE-8-02) [6] was developed for the design of cold formed stainless members. Tangent modulus method is adopted in this code to calculate the flexural buckling strength of stainless steel columns. Validation is required to check whether this method is still suitable for the strength predictions of welded I-columns. European design code (Eurocode3: Part 1.4) [7] uses Perry formula to predict the flexural buckling strengths of welded I-columns. In the Perry formula, the imperfection parameters for the design of low carbon steel columns are directly used for the design of stainless steel columns. As few test data are available, more test data on the welded I-columns are need to validate and to improve the design codes.

This paper presents a comprehensive experimental program on stainless steel welded I-columns, including the measurements of geometric dimension and imperfection, tensile coupon tests, stub columns tests, and long columns tests. Furthermore, the effect of the fabrication, including the shearing edge enhancement and the residual stresses, on the flexural buckling strengths of columns were investigated using finite element method. Finally, the strengths from the long column tests 
were compared with the predictions using the current design codes. Recommendations on the strength predictions for stainless steel welded I-columns are given.

\section{TEST PROGRAM}

The material used in the tests is austenitic stainless steel Grade 304. The surface of the virgin plate is No.1 Grade, i.e. no polishing and with color in silvery white. These plates were cut into strips by shearing machine, and then the strips were welded into I-columns using TIG welding. The columns were put into a reforming machine to reduce the imperfection due to the welding.

The nominal cross section used in the test is $100 \mathrm{~mm} \times 100 \mathrm{~mm} \times 6 \mathrm{~mm} \times 6 \mathrm{~mm}$. The test program consists of six material tensile coupon tests, two stub column tests and seven long column tests. Prior to the column tests, geometric dimensions were measured. Local imperfections and overall imperfections were measured for the stub columns and the long columns, respectively. Table 1 shows the measured geometric dimensions and imperfections.

Table 1. Measured Dimensions and Imperfections

\begin{tabular}{|c|c|c|c|c|c|c|c|}
\hline \multirow{2}{*}{ Test Type } & \multirow{2}{*}{ Specimens } & \multirow{2}{*}{$\frac{\text { Length }}{L(\mathrm{~mm})}$} & \multirow{2}{*}{$\frac{\text { Depth }}{H(\mathrm{~mm})}$} & \multirow{2}{*}{$\frac{\text { Width }}{B(\mathrm{~mm})}$} & \multirow{2}{*}{$\frac{\text { Thickness }}{t(\mathrm{~mm})}$} & \multicolumn{2}{|c|}{ Imperfection(mm) } \\
\hline & & & & & & Major & Minor \\
\hline \multirow{2}{*}{ Stub column } & $\mathrm{H}-\mathrm{S}-\mathrm{a}$ & 400 & \multirow{9}{*}{100} & \multirow{9}{*}{100} & \multirow{9}{*}{5.85} & $1.17 *$ & $1.08 *$ \\
\hline & H-S-b & 400 & & & & $1.51 *$ & $0.44 *$ \\
\hline \multirow{4}{*}{$\begin{array}{l}\text { Long column } \\
\text { Major axis }\end{array}$} & H-L-1500M & $1580^{\dagger}$ & & & & 0.79 & 1.33 \\
\hline & H-L-2000M & $2080^{\dagger}$ & & & & 2.39 & 1.39 \\
\hline & H-L-2500M & $2580^{\dagger}$ & & & & 2.39 & 2.35 \\
\hline & H-L-3000M & $3080^{\dagger}$ & & & & 1.81 & 2.73 \\
\hline \multirow{3}{*}{$\begin{array}{l}\text { Long column } \\
\text { Minor axis }\end{array}$} & H-L-1500R & $1580^{\dagger}$ & & & & 2.01 & 1.87 \\
\hline & H-L-2000R & $2080^{\dagger}$ & & & & 1.97 & 1.17 \\
\hline & H-L-2500R & $2580^{\dagger}$ & & & & 0.99 & 11.45 \\
\hline
\end{tabular}

Note: * these values are measured local imperfections. 'Major' and 'Minor' mean local imperfection of the flange and that of the web, respectively. $\dagger$ This length is the distance between the two knife-edges.

\subsection{Material Tests}

Material test coupons were cut from the columns by Spark Cutting machine. This machine does not introduce heat or cold work into the coupons during cutting. The cutting positions of the coupons on the cross section and the shape of the coupon are shown in Figure 1. Three coupons were cut from the center of the web, termed HZ-xx. Another three coupons were cut from the edge of the flange, termed HB-xx. The reason for the cutting the coupons from the flange edge is that we want to quantify the shear cutting effect on the material property.

Coupons were tested in a $100 \mathrm{kN}$ capacity MTS displacement controlled testing machine with friction grips. The load rate was $1 \mathrm{~mm} / \mathrm{min}$ controlled by the machine automatically. Pair of stain gauges were pasted on each face of the coupon. Stain were recorded until the stain gauge peeled off from the coupon. Figure 2 shows the material test setup.

Material test results were processed according to Eq. (1) (Gardner and Nethercot [8]). In this equation, $\sigma$ and $\varepsilon$ are engineering stress and strain, respectively, $E_{0}$ is the initial Young's modulus, $\sigma_{0.2}$ is the $0.2 \%$ proof stress (also called yield strength), $n$ is a strain hardening exponent, $\sigma_{1.0}$ is the $1.0 \%$ proof stress, and $n_{0.2,1.0}$ is a strain hardening coefficient representing a curve that passes 
through $\sigma_{0.2}$ and $\sigma_{1.0}$. Table 2 shows the material test results. In this table, $\sigma_{\mathrm{u}}$ is the ultimate stress, $\varepsilon_{\mathrm{t} 0.2}$ and $\varepsilon_{\mathrm{t} 1.0}$ are the total strain corresponding to $\sigma_{0.2}$ and $\sigma_{1.0}$, respectively.

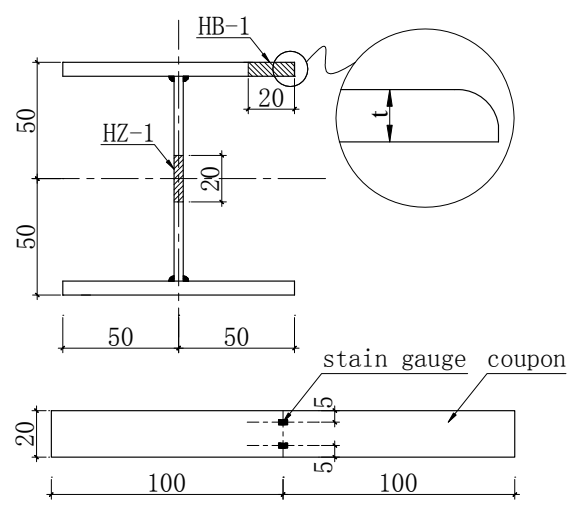

Figure 1. The Cutting Position and Dimensions of the Coupon

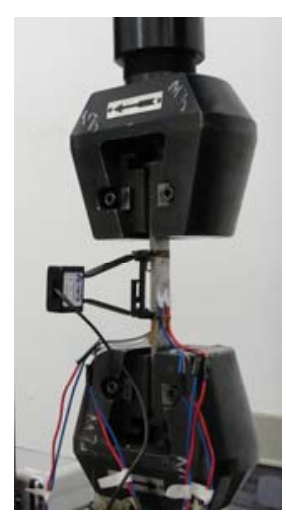

Figure 2. Material Test Setup

$$
\left\{\begin{array}{cl}
\varepsilon=\frac{\sigma}{E_{0}}+0.002\left(\frac{\sigma}{\sigma_{0.2}}\right)^{n} & \sigma \leq \sigma_{0.2} \\
\varepsilon=\frac{\sigma-\sigma_{0.2}}{E_{0.2}}+\left(0.008-\frac{\sigma_{1.0}-\sigma_{0.2}}{E_{0.2}}\right)\left(\frac{\sigma-\sigma_{0.2}}{\sigma_{1.0}-\sigma_{0.2}}\right)^{n_{0.2 .1 .0}^{\prime}}+\varepsilon_{t 0.2} & \sigma_{0.2} \leq \sigma \leq \sigma_{2.0}
\end{array}\right.
$$

Table 2. Material Properties from Tensile Coupon Tests

\begin{tabular}{cccccccccc}
\hline \multirow{2}{*}{ Coupons } & $E_{0}$ & $\sigma_{0.01}$ & $\sigma_{0.2}$ & $\sigma_{1.0}$ & $\sigma_{\mathrm{u} .}$ & \multirow{2}{*}{$e_{\mathrm{t} 0.2}$} & \multirow{2}{*}{$e_{\mathrm{t} 1.0}$} & $n$ & \multirow{2}{*}{$n_{0.2,1.0}$} \\
\cline { 2 - 9 } & $\mathrm{MPa}$ & $\mathrm{MPa}$ & $\mathrm{MPa}$ & $\mathrm{MPa}$ & $\mathrm{MPa}$ & & & \\
\hline HB-1 & 189347 & 91.13 & 249.30 & 298.88 & 708.77 & 0.0032 & 0.0116 & 2.98 & 2.00 \\
\hline HB-2 & 181645 & 104.33 & 267.89 & 307.19 & 700.17 & 0.0037 & 0.0117 & 3.18 & 1.70 \\
\hline HB-3 & 184405 & 118.69 & 271.02 & 325.23 & 687.55 & 0.0035 & 0.0118 & 3.63 & 2.30 \\
\hline AVG.HB & 185132 & 104.72 & 262.74 & 310.43 & 698.83 & 0.0034 & 0.0117 & 3.26 & 2.00 \\
\hline HZ-1 & 192295 & 93.23 & 235.76 & 283.96 & 674.84 & 0.0030 & 0.0115 & 3.23 & 2.30 \\
\hline HZ-2 & 190535 & 107.32 & 242.51 & 283.86 & 671.49 & 0.0033 & 0.0115 & 3.67 & 1.80 \\
\hline HZ-3 & 184632 & 103.49 & 247.10 & 291.45 & 672.08 & 0.0033 & 0.0116 & 3.44 & 2.00 \\
\hline AVG.HZ & 189154 & 101.35 & 241.79 & 286.43 & 672.80 & 0.0032 & 0.0115 & 3.45 & 2.03 \\
\hline
\end{tabular}


From Table 2, it is concluded that due to the shear cutting process, the proof stress $\sigma_{0.2}$ and ultimate stress $\sigma_{\mathrm{u}}$ of the coupons cut from the shearing edge were $20 \mathrm{MPa}$ higher than those of the coupons cut from the center of the web. That means the shear cutting process really introduces some degree of cold work into the shearing edge.

\section{$2.2 \quad$ Stub Column Tests}

Stub column tests were conducted in a $600 \mathrm{kN}$ capacity SCHENCK testing machine. Prior to the tests, the ends of stub columns were milled flat to ensure they were fully contacted with the load plate of the test machine. Seven stain gauges, six settled on the flanges and one on the center of the web at mid height, respectively, were used to measure the average compression strain of the cross section. Four displacement transducers (LVDT) were used to measure the axial shorting of the column. The positions of the strain gauges and the test arrangement are shown in Figure 3.

The test strengths are listed in Table 5. Load-displacement curves are presented in Figure 4.

Both of these two short columns failed in material yielding. Although the local imperfections of the stub columns in these tests were large (Avg. $=1.05 \mathrm{~mm}$ ), local buckling of the plate did not appear before the column reaching its ultimate strength (about $450 \mathrm{kN}$ ). That means the cross section is stocky enough to be considered fully effective in the design of long columns.

Strain-stress curves were obtained from stub column tests. The average strain from seven strain gauges was used as the strain, and the stress was calculated using the force divided by cross section area. Material properties from stub column tests were shown in Table 3. Comparing data in Table 2 with the data in Table 3, the initial elastic modulus from stub column tests are lower than those from the tensile coupon tests due to the existence of residual stresses, and the proof strengths from stub column tests are close to those from tensile coupon tests.
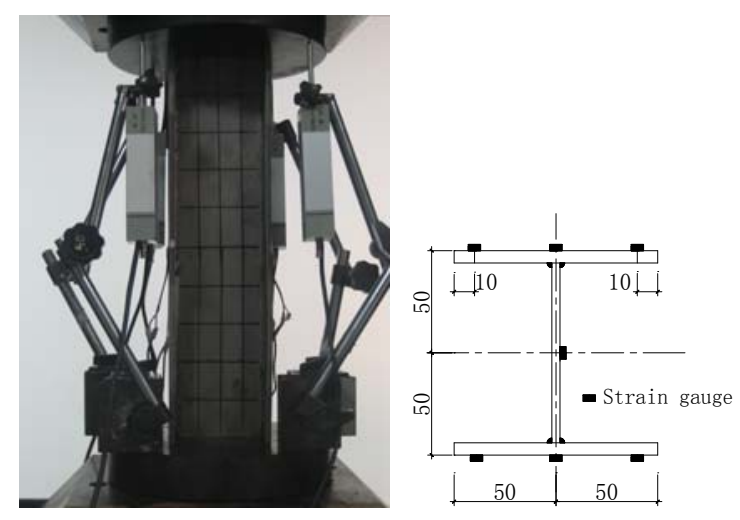

Figure 3. Stub column test setup and the positions of strain gauges

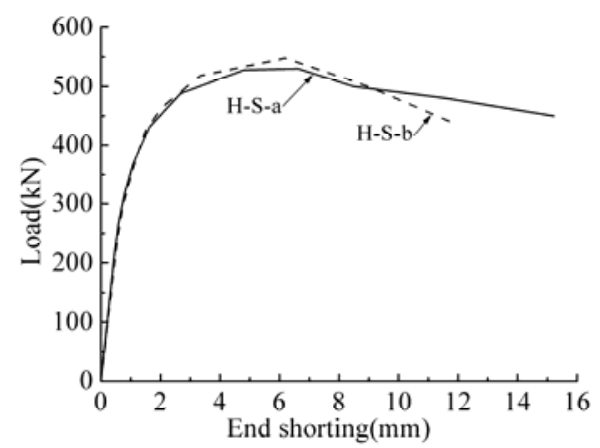

Figure 4. Load-End shorting curves of the stub column 
Table 3 Material properties from stub column tests

\begin{tabular}{ccccc}
\hline \multirow{2}{*}{ Specimens } & $E_{0}$ & $\sigma_{0.01}$ & $\sigma_{0.2}$ & \multirow{2}{*}{$n$} \\
\cline { 2 - 4 } & $\mathrm{MPa}$ & $\mathrm{MPa}$ & $\mathrm{MPa}$ & \\
\hline H-S-a & 174737 & 119.92 & 265.75 & 3.76 \\
\hline H-S-b & 179987 & 131.26 & 256.14 & 4.48 \\
\hline AVG. & 177362 & 125.59 & 260.95 & 4.12 \\
\hline
\end{tabular}

\subsection{Long Column Tests}

Long columns were tested in a $5000 \mathrm{kN}$ capacity hydraulic testing machine. One-way knife-edges were settled at both ends of the columns to make the columns pinned in one axis and fixed in the other one. Four columns were tested with pinned end condition in major axis, and three columns were tested with pinned end condition in minor axis.Test arrangement is shown in Figure 5. It should be noted that there was no rig settled at the mid height of the columns to restrain the lateral deformation.

Clamps were designed to prevent unwanted sliding between the column end and the load plate. Details of the clamps are given in Figure 6.

Tests were performed in a displacement-control model. A screw jack was settled at the bottom of the column. A LVTD was fixed under the bottom loading plate to help control the loading rate. Figure 7 shows the loading system in detail.

At each end of the column, four LVTDs, located at each corner of the end plate, were utilized to record the end plate rotations and the displacements. Another three LVTDs were assigned at the middle height of the column, two in the pinned direction and one in the fixed direction, respectively. At the top of the column, a load cell was used to record the applied load.

The test strengths are given in Table 5. Figure 8 and Figure 9 show the load-lateral displacement curves and the load-end shorting curves, respectively.

All the columns failed in the flexural buckling, and no local buckling was detected before the column reached its ultimate strength.

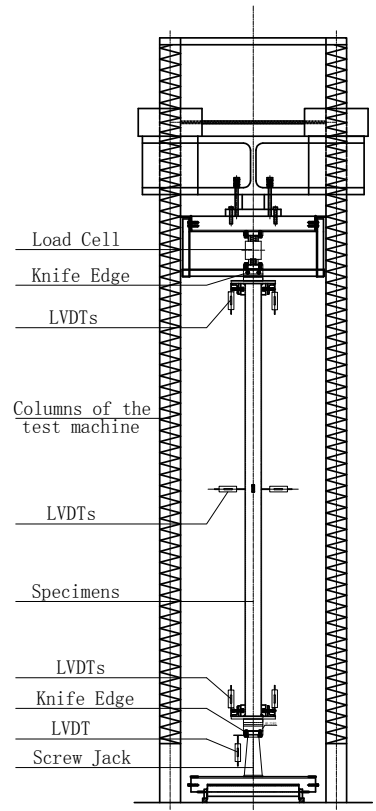

Figure 5. Long Column Test Setup 


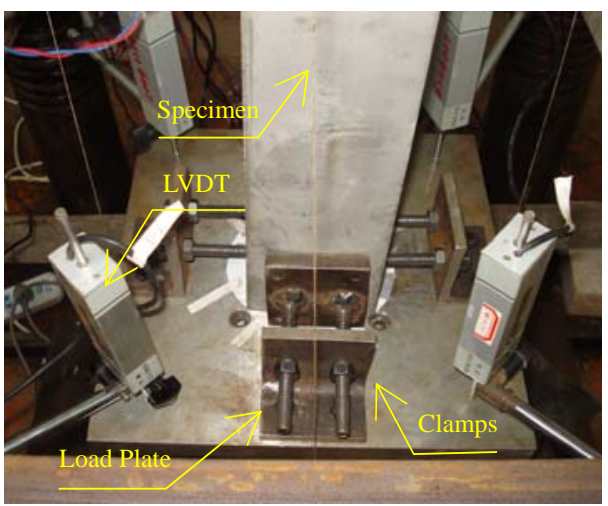

Figure 6. Clamps at the End of the Column

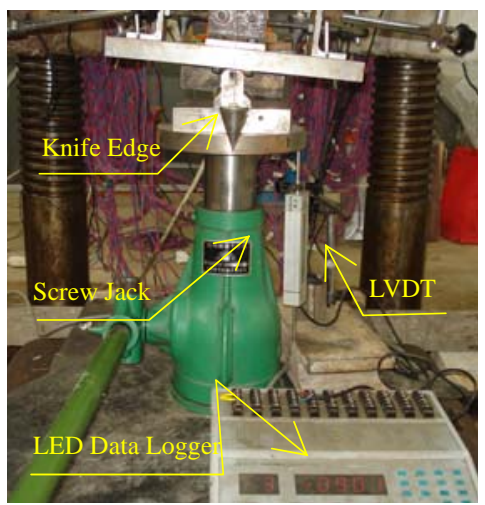

Figure 7. Details of the Loading System

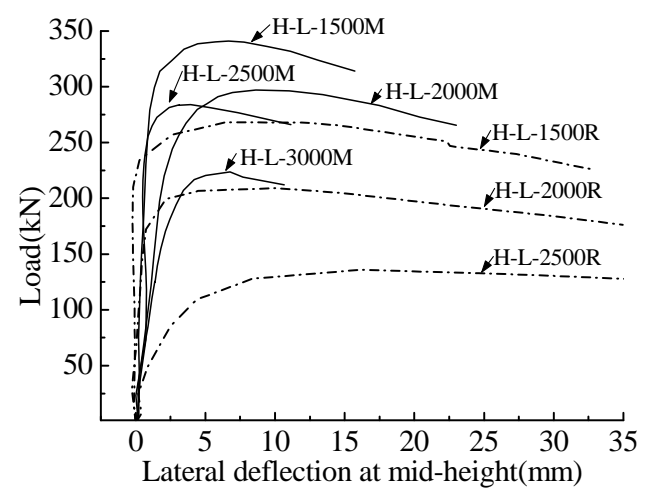

Figure 8. Load-lateral Deflection Curves of the Test Columns

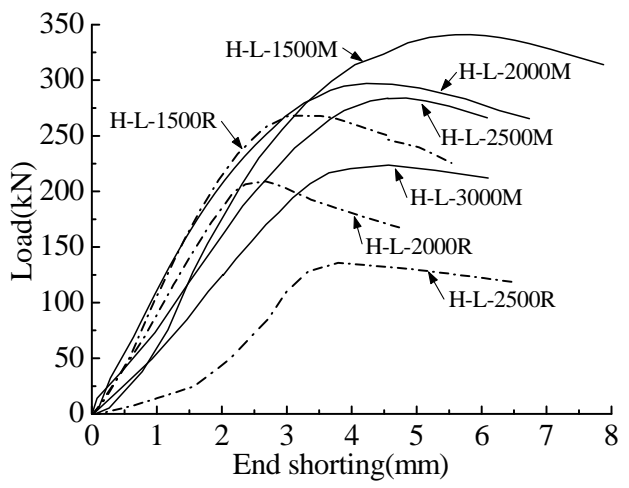

Figure 9. Load-end Shorting Curves of the Test Columns 


\section{FINITE ELEMENT ANALYSIS}

ANSYS [9] was employed to develop the finite element model. Nonlinear material properties, geometric imperfections, and residual stresses were introduced into the finite element model. The effects of the fabrication, the material enhancement at the shearing edge and the residual stresses due to welding, on the strength of stainless steel welded I-column were discussed.

\subsection{Material Model}

Three options for the material properties used in the finite element analysis: the material properties from the stub column tests, the material properties from the tensile coupon tests without enhancement in the flange edge, and the material properties from the tensile coupon tests with enhancement in the flange edge. For the material properties obtained from the stub column test, there was no parameter for the second part of Eq. 1. So, Eq. 2 (Quach et al. [10]) was used to calculate $\sigma_{1.0}$ and $n_{0.2,1.0}$. For the material properties from the tensile coupon tests without enhancement, the material properties from the coupon cut from the web were used for the whole cross section in the finite element model. For the material properties from the tensile coupon tests with enhancement, the material properties from the coupon cut from the flange edge were used for the edge region of the flange (20 $\mathrm{mm}$ wide from the edge), and the material properties from the coupons cut from the web were used for the rest region. Strain-stress curves used in finite element model are shown in Figure 10.

For the plastic loading, von Mises yield rule, associated flow rule, and isotropic hardening rule were utilized.

$$
\left\{\begin{array}{l}
\frac{\sigma_{1.0}}{\sigma_{0.2}}=0.662 \frac{1}{n}+1.085 \\
n_{0.2,1.0}=6.399\left(\frac{E_{0.2}}{E_{0}}\right)\left(\frac{\sigma_{1.0}}{\sigma_{0.2}}\right)+1.145
\end{array}\right.
$$

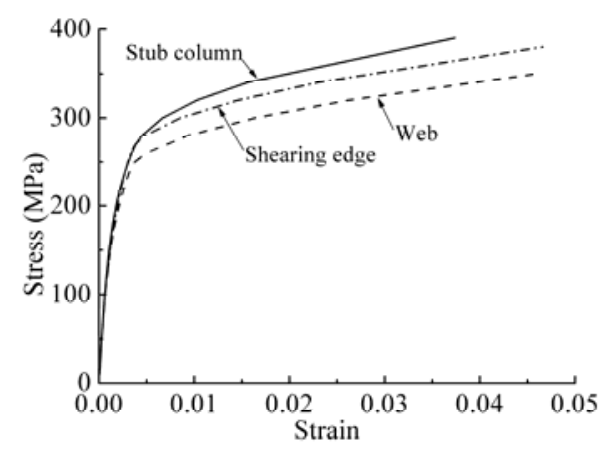

Figure 10. Strain-stress Curves used in Finite Element Model

\subsection{Element}

Shell 181, a 4-node structural shell element in ANSYS element library [9], was used. Shell 181 is suitable for analyzing thin to moderately thick shell structures. It is a 4-noded element with six degrees of freedom at each node with translations in the $\mathrm{X}, \mathrm{Y}$, and $\mathrm{Z}$ directions and rotations about the X, Y, and Z-axes. Shell 181 is well-suited for linear, large rotation and large strain nonlinear applications. 


\subsection{Boundary Conditions}

The boundary conditions for the stub column model and the long column model are shown in Figure 11. For the stub column model, constrain equations were used to make the displacement of the nodes at the loading end uniform in $\mathrm{Z}$ direction. At the loading end, all the degrees of freedom were fixed except the translational degree of freedom in $\mathrm{Z}$ direction. At the support end, all the degrees of freedom were fixed. The force was evenly applied on the nodes at the loading end. For the long column model, constraint equations were used to ensure that all the nodes at each end of the column act together as a rigid plane. A master node at each end represents the rigid plane. Typically, any node in the rigid plane can be used as the master node. Here, we used the node in the centroid of the cross section as the master node. Other nodes at this end were termed as slave nodes. The boundary conditions were applied on the master node. For the master node at the loading end, translational degrees of freedom in $\mathrm{X}$ and $\mathrm{Y}$ direction were fixed, and rotational degrees of freedom in $\mathrm{Y}$ and $\mathrm{Z}$ direction were fixed. For the master node at the support end, the boundary conditions were almost the same as those at the loading end, except that the translational degree of freedom in $\mathrm{Z}$ direction was also fixed. The force was applied on the master node at the loading end.

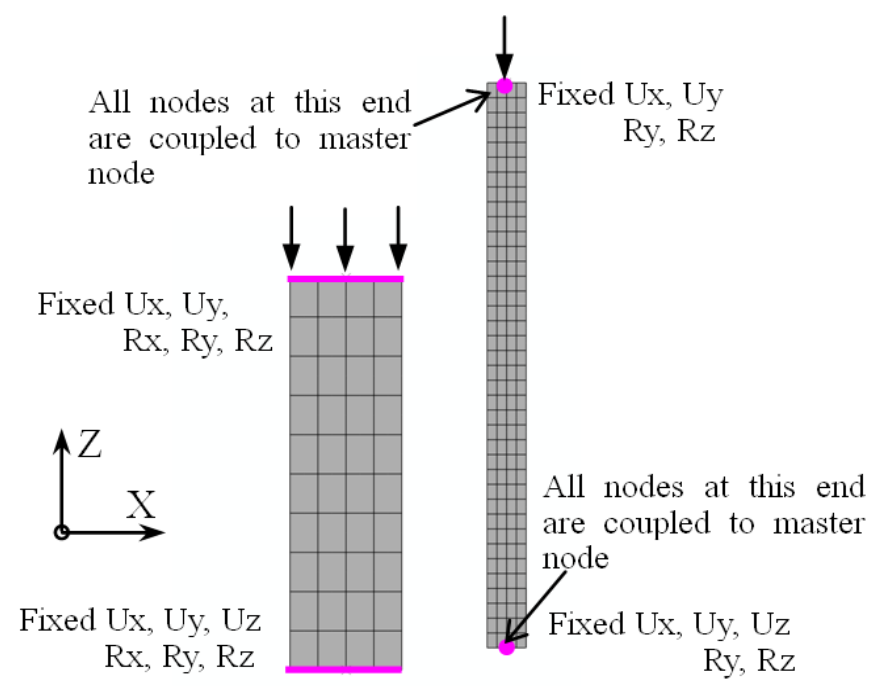

Figure 11. Boundary conditions for the stub columns and the long columns

\subsection{Geometric Imperfections and Residual Stresses}

Eigenbuckling modes were used as the shapes of the imperfections. Measured imperfection magnitudes were used as the magnitudes of imperfection. For the stub columns, only local imperfection was taken into account. For the long columns, both local imperfection and overall imperfection were introduced into the finite element model.

The residual stresses mode proposed by Wang et al. [11] were used in this paper. Wang et al. [11] measured the residual stresses in the stainless steel welded I-section of Grade 316. Figure 12 shows the residual stresses distribution mode and the residual stresses distribution introduced into finite element model. It should be noted that for the finite element model that uses the material properties from the stub column tests, residual stresses were not introduced into that model. 

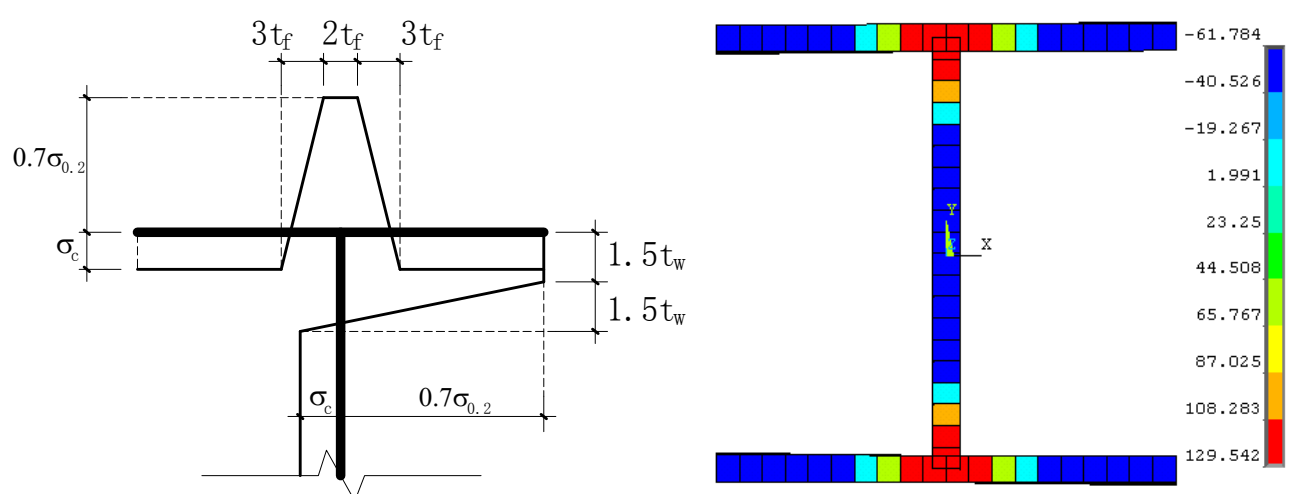

Figure 12. Residual stresses distribution mode proposed by Wang et al. [11]

\subsection{Analysis Cases}

For each column, finite element model was run five times with different material properties options and residual stresses options. Analysis cases are shown in Table 4.

Table 4. Analysis Cases for Each Column

\begin{tabular}{|c|c|c|c|c|c|}
\hline \multirow[b]{2}{*}{ Cases } & \multicolumn{3}{|c|}{ Material property options } & \multicolumn{2}{|c|}{ Residual stress options } \\
\hline & Stub columns & $\begin{array}{c}\text { Coupon tests } \\
\text { With enhancement }\end{array}$ & $\begin{array}{l}\text { Coupon tests } \\
\text { Without enhancement }\end{array}$ & With & Without \\
\hline$F_{\mathrm{w}}$ & & & $\sqrt{ }$ & & $\sqrt{ }$ \\
\hline$F_{\mathrm{c}}$ & & $\sqrt{ }$ & & & $\sqrt{ }$ \\
\hline$F_{\mathrm{r}}$ & & & $\sqrt{ }$ & $\sqrt{ }$ & \\
\hline$F_{\mathrm{r}+\mathrm{c}}$ & & $\sqrt{ }$ & & $\sqrt{ }$ & \\
\hline$F_{\mathrm{s}}$ & $\sqrt{ }$ & & & & \\
\hline
\end{tabular}

\subsection{Finite Element Analysis Results}

The finite element analysis results are listed in Table 5.

Table 5. Comparisons of the Test Results and the Finite Element Analysis Results

\begin{tabular}{|c|c|c|c|c|c|c|c|}
\hline Test Type & Specimens & $\frac{\text { Ultimate Load }}{F(\mathrm{kN})}$ & $F_{w} / F_{t}$ & $F_{c} / F_{t}$ & $F_{r} / F_{t}$ & $F_{r+c} / F_{t}$ & $F_{s} / F_{t}$ \\
\hline \multirow{2}{*}{ stub columns } & H-S-a & 530 & \multirow{2}{*}{0.846} & \multirow{2}{*}{0.870} & \multirow{2}{*}{0.845} & \multirow{2}{*}{0.868} & \\
\hline & H-S-b & 548 & & & & & \\
\hline \multirow{4}{*}{ major axis } & H-L-1500M & 341 & 1.086 & 1.111 & 1.084 & 1.109 & 1.160 \\
\hline & H-L-2000M & 297 & 1.034 & 1.055 & 1.039 & 1.064 & 1.099 \\
\hline & H-L-2500M & 284 & 0.941 & 0.967 & 0.948 & 0.959 & 1.000 \\
\hline & H-L-3000M & 224 & 1.045 & 1.063 & 1.061 & 1.079 & 1.128 \\
\hline \multirow{5}{*}{ minor axis } & H-L-1500R & 268 & 0.964 & 0.994 & 0.905 & 0.937 & 1.026 \\
\hline & H-L-2000R & 209 & 0.980 & 1.004 & 0.897 & 0.925 & 1.048 \\
\hline & H-L-2500R & 136 & 0.875 & 0.896 & 0.817 & 0.842 & 0.929 \\
\hline & Avg. & & 0.989 & 1.013 & 0.964 & 0.988 & 1.056 \\
\hline & S.Dev & & 0.071 & 0.071 & 0.099 & 0.098 & 0.080 \\
\hline
\end{tabular}


From Table 5, it is concluded that:

(1). All the five analysis cases can predict the column strength well. The average ratios of the finite element analysis results over the test results are around 1.0, with the maximum deviations less than 0.1. However, it seems the finite element model does not work well for the stub columns. Ashraf et al.[12], and Bredenkamp and Van den Berg [4] also mentioned this phenomenon. That may be attributed to the welding. First, the area of the cross section increases due to the welding filler. Second, the heat, released in the welding process, changes the microstructure of the region alongside the welding, which may improve the material strength in the heat-affected zone.

(2). Compared the results of the analysis cases with shearing edge enhancement $\left(F_{\mathrm{c}}\right)$ and the model without that $\left(F_{\mathrm{w}}\right)$, we can conclude that the shearing edge enhancement can increase the column strength by $2 \% \sim 3 \%$.

(3). Compared the results of the analysis cases with residual stresses $\left(F_{\mathrm{r}}\right)$ and the model without that $\left(F_{\mathrm{w}}\right)$, it can be concluded that the effect of residual stresses on the column strength is obviously different for columns buckled in major axis and for columns buckled in minor axis. For columns buckled in major axis, residual stresses almost have no effect on the column strengths. While for columns buckled in minor axis, residual stresses can decrease the column strengths by $6 \% \sim 7 \%$. That is mainly due to the residual stresses distribution where the maximum compressive stress happens at the far end of the minor axis.

\section{COMPARISON OF TEST STRENGTHS WITH DESIGN STRENGTHS}

\subsection{Test Database}

Bredenkamp and Van den Berg [4] reported 13 long column tests on welded I 140×70×4.0×3.5 and I $180 \times 90 \times 6.0 \times 4.5$, and the material is 3CR12. Burgan et al. [5] reported 15 long column tests on welded I $160 \times 80 \times 6 \times 10$ and I $160 \times 160 \times 10 \times 6$, and the material is austenitic 1.4031 (S304) and duplex 1.4462 (S31803).

In Reference 4, all the tested sections are very slender. So the effective area should be calculated before the predictions of the column strength. In order to avoid the error from the determination of the effective area, this set of test data is not considered here.

Combined with the column tests in this paper, a total of 22 test data are obtained.

\subsection{Current Design Codes}

American design code (SEI/ASCE 8-02) [6] and European design code (Eurocode3: Part 1.4) [7] are considered here.

Perry formula is adopted in European design code to calculate the flexural buckling strength of stainless steel column. The reduction factor $\chi$ is defined as follows:

$$
\begin{aligned}
& \chi=\frac{1}{\phi+\sqrt{\phi^{2}-\lambda^{2}}} \leq 1 \\
& \phi=0.5\left[1+\eta+\lambda^{2}\right]
\end{aligned}
$$


where $\eta$ is imperfection parameter $=\alpha\left(\lambda-\lambda_{0}\right)$. For welded I-columns buckled in major axis, $\alpha$ and $\lambda_{0}$ are equal to 0.49 and 0.20 , respectively. For welded I-columns buckled in minor axis, $\alpha$ and $\lambda_{0}$ are equal to 0.76 and 0.20 , respectively.

In American design code, the tangent modulus theory is adopted. The flexural buckling stress, $F_{\mathrm{n}}$, is defined by Eq. 5 .

$F_{\mathrm{n}}=\frac{\pi^{2} E_{\mathrm{t}}}{(K L / r)^{2}} \leq F_{\mathrm{y}}$

where $F_{\mathrm{n}}$ is the flexural buckling stress; $E_{\mathrm{t}}$ is the tangent modulus in compression corresponding to buckling stress; $K$ is the effective length factor; $L$ is the unbraced length of members; $r$ is the radius of gyration of full, unreduced cross section. Iterations are necessary in solving buckling stress.

\subsection{Comparisons}

Figure 13 shows the test strengths and the column curves from the design codes. It should be noted here that in the calculations of the column curves using the design codes, material properties from tensile coupon tests cut from the web center were used $\left(E_{0}=189154 \mathrm{MPa}, \sigma_{0.2}=241.79 \mathrm{MPa}\right.$, $n=3.45$ ). In addition, the partial factors (such as $\gamma_{\mathrm{m}}$ in the European design code) were set to 1.0.

In Figure 13, 'EN-major' and 'EN-minor' mean the column curves in the European design code for the welded I-column buckled in major axis and the column buckled in minor axis, respectively; 'ASCE' means the column curve in the American design code.

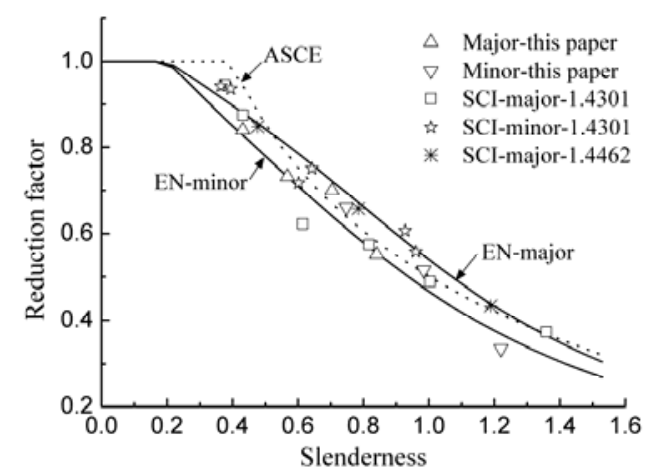

Figure 13. Comparisons between the Test Strengths and the Predictions of Design Codes

From Figure 13, those conclusions could be dawn:

(1) Most of the test data locate between the column curve for columns buckled in major axis and the column curve for the columns buckled in minor axis in the European design code.

(2) There is no obvious difference in the reduction factor for columns buckled in major axis and columns buckled in minor axis.

(3) American design code predicts the column strength well for columns with comparatively large slenderness. For columns with small slenderness, the predictions are unconservative. 
(4) Conservatively, the column curves in European design code for columns buckled in minor axis can be used as the design curve for welded I-column buckled in major axis and column buckled in minor axis.

\section{CONCLUSIONS}

(1) A series of tests on stainless steel welded I-columns were carried out. Two stub columns and seven long columns were tested. The stub columns failed in material yielding, and the long columns failed in flexural buckling.

(2) The effect of the fabrication process on the column buckling strengths were investigated using the finite element method. The shear cutting in cutting the plate into strips, can increase the material strength along the cutting edge, and this type of material enhancement can improve the column strength by $2 \% \sim 3 \%$. The residual stresses caused in welding process can decrease strength of welded I-column buckled in minor axis by $6 \% \sim 7 \%$, while it has no effect on the strength of column buckled in major axis.

(3) The column curve in European design code for columns buckled in minor axis can be used as the design curve for welded I-columns buckled in major axis and columns buckled in minor axis.

\section{ACKNOWLEDGMENTS}

The research work described in this paper is supported by the Priority Academic Program Development of Jiangsu Higher Education Institutions and by the National Science Foundation of China through the projects No. 51178098, No. 51378105 and 51578134. The financial support is highly appreciated.

\section{REFERENCE}

[1] Kuwamura, H., "Local Buckling of Thin-walled Stainless Steel Members”, Steel Structures, 2003, Vol. 3, pp. 191-201.

[2] Saliba, N. and Gardner, L., "Cross-section Stability of Lean Duplex Stainless Steel Welded I-sections”, Journal of Constructional Steel Research, 2013, Vol. 80, No. 1, pp. 1-14.

[3] Yuan, H.X., Wang, Y.Q., Shi, Y.J. and Gardner, L., "Stub Column Tests on Stainless Steel Built-up Sections", Proceedings of the Fourth International Experts Seminar of Stainless Steel in Structures. Ascot, UK, 2012, pp. 1-14.

[4] Bredenkamp, P.J. and Van den Berg, G.J., "The Strength of Stainless Steel Built-up I-section Columns”, Journal of Constructional Steel Research, 1995, Vol. 34, No. 2-3, pp. 131-144.

[5] Burgan, B.A., Baddoo, N.R. and Gilsenan, K.A., "Structural Design of Stainless Steel Members-comparison between Eurocode 3, Part 1.4 and Test Results”, Journal of Constructional Steel Research, 2000, Vol. 54, No. 1, pp. 51-73.

[6] ASCE., "Specification for the Design of Cold-formed Stainless Steel Structural Members", American Society of Civil Engineers, SEI/ASCE-8-02, Reston, Virginia, 2002.

[7] EC3., "Eurocode 3: Design of Steel Structures - Part 1.4: General Rules - Supplementary Rules for Stainless Steels”, European Committee for Standardization, ENV 1993-1-4, CEN, Brussels, 2006. 
[8] Gardner, L. and Nethercot, D.A., "Experiments on Stainless Steel Hollow Sections - Part 1: Material and Cross-sectional Behavior”, Journal of Constructional Steel Research, 2004, Vol. 60, No. 9, pp. 1291-1318.

[9] ANSYS. Release, 10.0 Documentation, ANSYS Inc, Canonsburg, PA, 2005.

[10] Quach, W.M., Teng, J.G. and Chung, K.F., "Three-stage Full-range Stress-strain Model for Stainless Steels”, Journal of Structural Engineering, 2008, Vol. 134, No. 9, pp. 1518-1527.

[11] Wang, Y.Q., Guan, J. and Yong, Z., et al., "Experimental Study on the Residual Stress of Austenitic Stainless Steel 316 at I-section”, Industrial Building, 2012, Vol. 42, No. 5, pp. 45-50 (in Chinese).

[12] Ashraf, M., Gardner, L. and Nethercot, D.A. "Finite Element Modeling of Structural Stainless Steel Cross-sections”, Thin-Walled Structures, 2006, Vol. 44, No. 10, pp. 1048-1062. 